\title{
Efficiency of enteral nitrogen support in surgical patients: small peptides $v$ non-degraded proteins
}

\author{
F Ziegler, J Ḿ Ollivier, L Cynober, J P Masini, C Coudray-Lucas, E Levy, J Giboudeau
}

\begin{abstract}
In a prospective study, 12 intensive care patients, after abdominal surgery, received three alternate six-day courses of two enteral diets with identical nitrogen $(0.3 \mathrm{~g} \mathrm{~N} / \mathrm{kg}$ per day) and energy (60 kcal/kg per day) supply. The protein hydrolysate (PH) diet contained enzyme-hydrolysed casein and lactoserum (60\% small peptides), while the non-degraded protein (NDP) diet contained a nitrogen source of similar amino acid composition, but in the form of non-degraded proteins. The patients were randomised to receive either PH-NDP-PH or NDP-PH-NDP. Parameters reflecting protein metabolism were assessed in the plasma, urine, and stomal effluent on days $1,6,12$, and 18 , three hours after stopping the nutrition (t0), and one hour after restarting it (t1).

Comparisons of $t \mathrm{l}$ and $\mathrm{t} 0$ values showed that 13 amino acids (including the eight essential amino acids) increased significantly with the protein hydrolysate diet, but only two increased with the non-degraded protein diet. Similarly, with protein hydrolysate, insulinaemia at tl was significantly higher than at to and correlated with plasma leucine, phenylalanine, alanine, and lysine concentrations. In addition, significant improvements in plasma albumin, transferrin, and retinol binding protein concentrations were seen with protein hydrolysate, together with a significant decrease in the plasma phenylalanine/tyrosine ratio and urinary 3-methylhistidine excretion. We conclude that in patients in intensive care after abdominal surgery enteral support containing small peptides is more effective than an equivalent diet containing whole proteins in restoring plasma amino acid and protein levels.
\end{abstract}

It is now recognised that enteral nutrition is an effective means of providing nutritional support in postoperative patients. ${ }^{12}$ Since amino acids are required to support protein synthesis, in particular for wound healing, for immunological defenses, and to prevent muscle wasting, ${ }^{3-6}$ the form of nitrogen supply - for example, whole proteins, proteolysates, free amino acids - has a central place in the conception of the diet. This has been the subject of considerable discussion, however. ${ }^{78}$

In the case of abdominal surgery where the hydrolytic capacities of the digestive tract are reduced, it becomes important to provide nitrogen in the most readily absorbable form. The use of predigested diets, providing a mixture of peptides of varying chain lengths, including dipeptides and tripeptides, is based on evidence that transport of short chain peptides is more efficient than that of free amino acids into enterocytes. ${ }^{9-14}$ Furthermore, it has been shown ${ }^{15} 16$ that the efficiency of proteolysate absorption is highly dependent on the relative amounts of dipeptides and tripeptides.

The results of clinical studies comparing proteolysates with whole protein based diets have been far from convincing; in effect, either a limited number of parameters were studied ${ }^{17}{ }^{18}$ or the number of patients was small. ${ }^{19} 20$

In the present work we compared the absorption of nitrogen supplied either in the form of a partial protein hydrolysate or the corresponding native proteins. The study was carried out in intensive care patients who had had abdominal surgery and were receiving continuous enteral nutrition.

\section{Patients and methods}

\section{PATIENTS}

The study was carried out in 12 intensive care patients (nine men, three women) who had undergone abdominal surgery in our institution. They had been referred to us from other centres after having had at least one laparotomy. The patients were aged 50 (19) years (mean (SD)) (Table I).

No renal failure, hepatic failure, or obesity was noted. The length of the small intestine after surgery was at least $1.5 \mathrm{~m}$ and all patients except case 2 had one or more stoma. Immediately after surgery the patients received total parenteral nutrition for $24-48$ hours. They were then given continuous enteral nutrition with a standard diet containing whole proteins; calorie intake was progressively increased to $60 \mathrm{kcal} / \mathrm{kg}$ per day over one week. ${ }^{2}$ The study was carried out 23 (13) days (mean (SD)) after surgery.

\section{DIETS}

The only difference between the two diets used (protein hydrolysate and non-degraded protein) concerned the qualitative nature of the nitrogen supply. The protein hydrolysate contained in the protein hydrolysate diet (Reabilan, Roussel Uclaf) was obtained by enzymatic hydrolysis of the native proteins contained in the nondegraded protein diet (2/3 casein and 1/3 lactoserum) (Table II). Both diets were kindly provided by Roussel Uclaf Nutrition, Puteaux, France. Of 100 peptides in the protein hydrolysate diet, 40 consist of two to four amino acids (manufacturer's data). Total hydrolysis of the two mixtures $(6 \mathrm{~N} \mathrm{HCl}, 24$ hours) indicated that their amino acid composition was similar (less than 1 to $9 \%$ difference according to the amino 
TABLE I Clinical data

\begin{tabular}{|c|c|c|c|c|c|c|c|c|c|c|}
\hline $\begin{array}{l}\text { Case } \\
\mathrm{No}^{\star}\end{array}$ & Sex & $\begin{array}{l}\text { Age } \\
\text { (years) }\end{array}$ & $\begin{array}{l}\text { Height } \\
(m)\end{array}$ & $\begin{array}{l}\text { Weight } \\
(k g)\end{array}$ & Diagnosis & Surgery & $\begin{array}{l}\text { Time between } \\
\text { surgery and } \\
\text { study (days) }\end{array}$ & $\begin{array}{l}\text { Tube } \\
\text { position }\end{array}$ & $\begin{array}{l}\text { Stoma } \\
\text { position }\end{array}$ & Groupt \\
\hline 1 & $\mathbf{M}$ & 28 & $1 \cdot 72$ & 70 & Peritonitis acute pancreatitis & $\begin{array}{l}\text { Subtotal colectomy } \\
\text { sigmoidostomy }\end{array}$ & 20 & Jejunum & Ileum & B \\
\hline $\begin{array}{l}2 \\
3\end{array}$ & $\begin{array}{l}M \\
M\end{array}$ & $\begin{array}{l}53 \\
49\end{array}$ & $\begin{array}{l}1 \cdot 66 \\
1 \cdot 70\end{array}$ & $\begin{array}{l}70 \\
80\end{array}$ & $\begin{array}{l}\text { Gastric tumour } \\
\text { Gastric tumour }\end{array}$ & $\begin{array}{l}\text { Abscess drainage } \\
\text { Subtotal gastrectomy } \\
\text { +multiple drainage }\end{array}$ & $\begin{array}{l}18 \\
10\end{array}$ & $\begin{array}{l}\text { Jejunum } \\
\text { Jejunum }\end{array}$ & $\begin{array}{l}\text { No stoma } \\
\text { Ileum }\end{array}$ & $\begin{array}{l}\text { B } \\
\text { A }\end{array}$ \\
\hline $\begin{array}{l}4 \\
5\end{array}$ & $\begin{array}{l}M \\
M\end{array}$ & $\begin{array}{l}46 \\
16\end{array}$ & $\begin{array}{l}1 \cdot 78 \\
1 \cdot 70\end{array}$ & $\begin{array}{l}61 \\
66\end{array}$ & $\begin{array}{l}\text { Bilharzian vesical tumour } \\
\text { Abdominal bullet wounds }\end{array}$ & $\begin{array}{l}\text { Small intestine resection } \\
\text { Small intestine resection } \\
\text { +multiple drainage }\end{array}$ & $\begin{array}{l}60 \\
75\end{array}$ & $\begin{array}{l}\text { Stomach } \\
\text { Stomach }\end{array}$ & $\begin{array}{l}\text { Jejunum } \\
\text { Jejunum }\end{array}$ & $\begin{array}{l}\text { A } \\
\text { B }\end{array}$ \\
\hline $\begin{array}{l}6 \\
7 \\
8\end{array}$ & $\begin{array}{l}\mathrm{F} \\
M \\
M\end{array}$ & $\begin{array}{l}29 \\
77 \\
62\end{array}$ & $\begin{array}{l}1 \cdot 57 \\
1 \cdot 75 \\
1 \cdot 77\end{array}$ & $\begin{array}{l}40 \\
65 \\
60\end{array}$ & $\begin{array}{l}\text { Abdominal occlusion } \\
\text { Peritonitis } \\
\text { Peritonitis }\end{array}$ & $\begin{array}{l}\text { Small intestine resection } \\
\text { Small intestine resection } \\
\text { Small intestine resection } \\
\text { + multiple drainage }\end{array}$ & $\begin{array}{l}40 \\
11 \\
27\end{array}$ & $\begin{array}{l}\text { Stomach } \\
\text { Stomach } \\
\text { Stomach }\end{array}$ & $\begin{array}{l}\text { Jejunum } \\
\text { Jejunum } \\
\text { Jejunum }\end{array}$ & $\begin{array}{l}\text { B } \\
\text { B } \\
\text { A }\end{array}$ \\
\hline $\begin{array}{r}9 \\
10 \\
11\end{array}$ & $\begin{array}{l}\mathrm{M} \\
\mathbf{M} \\
\mathrm{F}\end{array}$ & $\begin{array}{l}72 \\
51 \\
49\end{array}$ & $\begin{array}{l}1.62 \\
1.62 \\
1.53\end{array}$ & $\begin{array}{l}65 \\
62 \\
52\end{array}$ & $\begin{array}{l}\text { Peritonitis } \\
\text { Peritonitis } \\
\text { Peritonitis }\end{array}$ & $\begin{array}{l}\text { Colectomy, drainage } \\
\text { Hemicolectomy } \\
\text { Cholecystectomy }\end{array}$ & $\begin{array}{l}14 \\
50 \\
33\end{array}$ & $\begin{array}{l}\text { Stomach } \\
\text { Stomach } \\
\text { Stomach }\end{array}$ & $\begin{array}{l}\text { Ileum } \\
\text { Ileum } \\
\text { Jejunum } \\
\text { +ileum }\end{array}$ & $\begin{array}{l}\text { B } \\
\text { A } \\
\text { A }\end{array}$ \\
\hline 12 & $\mathbf{F}$ & 70 & $1 \cdot 60$ & 65 & Sigmoiditis peritonitis & $\begin{array}{l}\text { Cholecystectomy } \\
\text { enterolysis }\end{array}$ & 33 & Stomach & Jejunum & A \\
\hline
\end{tabular}

^In chronological order; †Group A: PH-NDP-PH; group B: NDP-PH-NDP.

acid; data not shown). (More details about the protein hydrolysate diet can be found in European Patent 0022019: Hydrolysat enzymatique total de proteines de lactosérum - obtention et application. INRA. J L Maubois et al.) The diets were strictly identical in terms of carbohydrate and lipid contents.

\section{EXPERIMENTAL DESIGN (Fig 1)}

The 18 day study was divided into three periods of six days. The patients were randomised to receive either protein hydrolysate or nondegraded protein during the first six days, starting on day 0 (D0). The diet was then reversed on day 6 (D6) and changed again on D12 (with a return to the first administered diet). There were thus two possible diet sequences, PH-NDP-PH (group A) or NDP-PH-NDP (group B).

As the patients each received protein hydrolysate and non-degraded protein alternately, each was his or her own control.

Samples were taken on D0 immediately before the study, and then on D1, D6, D12, and D18, three hours after stopping nutrition $(\mathrm{t} 0)$, and one hour after nutrition was restarted $(\mathrm{t} 1)$. The diet was changed after the $t \mathrm{l}$ sample had been taken (except on D1).

For each patient, urinary and chyme + faeces nitrogen excretion, and nitrogen balance $(\Delta N)$ were calculated as the mean of the last three days of each six day period.

The procedures followed were in accord with the Helsinki Declaration of 1975.

TABLE II Diet characteristics

\begin{tabular}{lll}
\hline & Protein hydrolysate & Non-degraded protein \\
\hline Energy supply (kcal/kg per day): & 60 & 60 \\
Target value & & $58(9)$ \\
Effective intake (mean (SD)) & $59(9)$ & $0 \cdot 3$ \\
Nitrogen supply (g/kg per day): & $0 \cdot 3$ & $0 \cdot 29(0 \cdot 05)$ \\
Target value & $0 \cdot 30(0 \cdot 04)$ & $1 / 200$ \\
Effective intake (mean (SD)) & $1 / 200$ & Lactoserum $1 \cdot 05$ \\
Nitrogen/total kcal & - & Casein $2 \cdot 10$ \\
Protein content $(\mathrm{g} / 100 \mathrm{ml}):$ & Hydrolysis of non-degraded protein & No treatment \\
Treatment of proteins & by trypsin and chymotrypsin & - \\
Result of hydrolysis & Peptides (by number) & \\
& 24 amino acids: $30 \%$ & \\
& 2-4 amino acids: $40 \%$ & \\
& Free amino acids: $30 \%$ & \\
\hline
\end{tabular}

\section{SAMPLE HANDLING}

\section{Blood}

Venous blood was drawn into heparinised tubes (for blood glucose, amino acids, and insulin measurement) or heparin free tubes (for total and specific proteins). Blood glucose was measured immediately and plasma was stored at $-20^{\circ} \mathrm{C}$ for no longer than one month before analysis of the other parameters. For amino acids assays, samples were deproteinised with sulphosalicylic acid $(50 \mathrm{mg} / \mathrm{ml})$ before storage.

\section{Urine}

Urea, creatinine, and 3-methylhistidine were measured in 24 hour urine samples.

\section{Luminal content}

Intestinal chyme samples were taken at the jejunostoma or ileostoma (except in case 2). In the patient with multiple stomas (case 11; see Table I) samples were taken at the distal (ileal) stoma. $^{21}$

\section{ASSAYS}

\section{Amino acids}

Assays were performed by means of high pressure ion exchange chromatography, using a Chromakon 500 (Kontron, Switzerland), which allows the separation of the 20 principal amino acids, including tryptophan and 3methylhistidine. ${ }^{22}$

\section{Proteins}

Serum total proteins were measured using the Biuret method (Astra 8, Beckman, USA). Total proteins in luminal samples were measured using the micro Lowry method after dilution $(1 / 400)$ in physiological saline. Serum retinol binding protein was measured by radial immunodiffusion (LC Partigen, Behring, FRG), serum transthyretin and transferrin by laser nephelementry, and serum albumin by electrophoresis. 


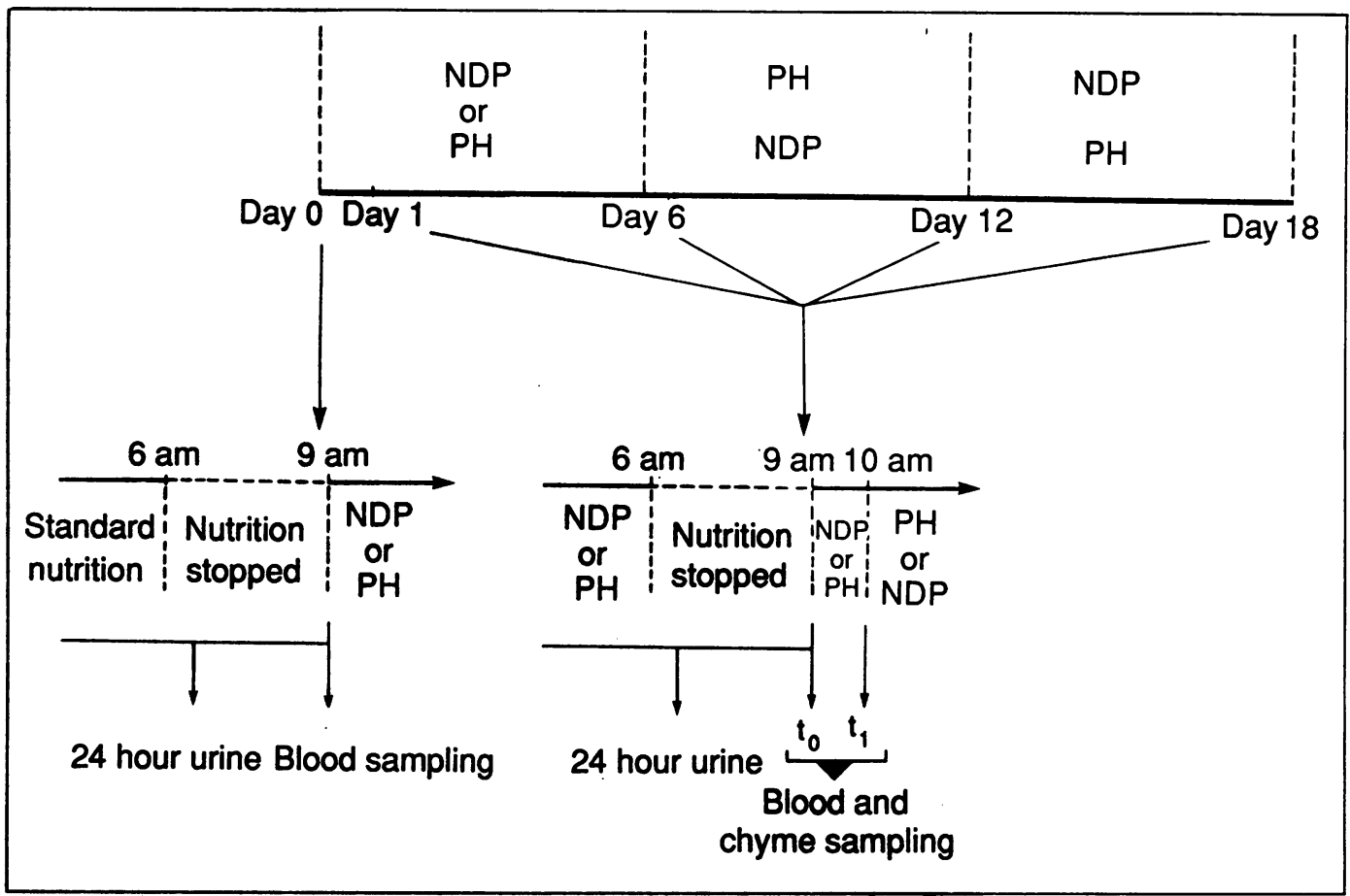

Figure 1: Experimental design. $N D P=$ non-degraded protein; $P H=$ protein hydrolysate.

Total nitrogen

Dietary, urinary, luminal, and faecal total nitrogen were measured using the Kjeldahl method (Büchi $320 \mathrm{~N}_{2}$ Distillation Unit).

\section{Insulin}

Plasma insulin was measured using radioimmunoassay (SB-INSI 5, International-CIS). For technical reasons insulin was not measured in case 3 (group A) or case 2 (group B).

\section{STATISTICS}

Statistical analysis was performed with nonparametric tests using a computerised statistics package (PCSM, Deltasoft, Grenoble, France).

The Mann-Whitney U test was used to compare the two groups of patients before the study. As each patient was his or her own control, the Wilcoxon $T$ test was used for the following comparisons: (a) State of plasma and chyme parameters one hour after nutrition restart $(t 1 v$ t0), regardless of the day of measurement. (b) Comparison of plasma and urine parameters after six days with protein hydrolysate or nondegraded protein, and after 18 days with either PH-NDP-PH or NDP-PH-NDP. (c) Comparison of plasma and urine parameters and nitrogen balance at the end of each diet period.

The Spearman rank test was used for assessing intervariable correlations.

\section{Results}

BIOCHEMICAL PARAMETERS IMMEDIATELY BEFORE THE STUDY

The two groups of patients were compared on Do, before beginning the nutritional study. There was no significant difference between the two groups for plasma and urinary parameters (plasma essential amino acids, specific serum proteins, and the urinary 3-methylhistidine/ creatinine ratio) (data not shown). Slightly lower values than normal were noted for some plasma amino acids (serine, alanine, valine, methionine, isoleucine, leucine, ornithine, histidine in both groups; taurine, threonine, cysteine, tryptophan in group A and glutamine, glycine, lysine in group B). Serum concentrations of specific proteins were generally close to the lowest values of the normal range.

\section{Group A}

\section{Group B}
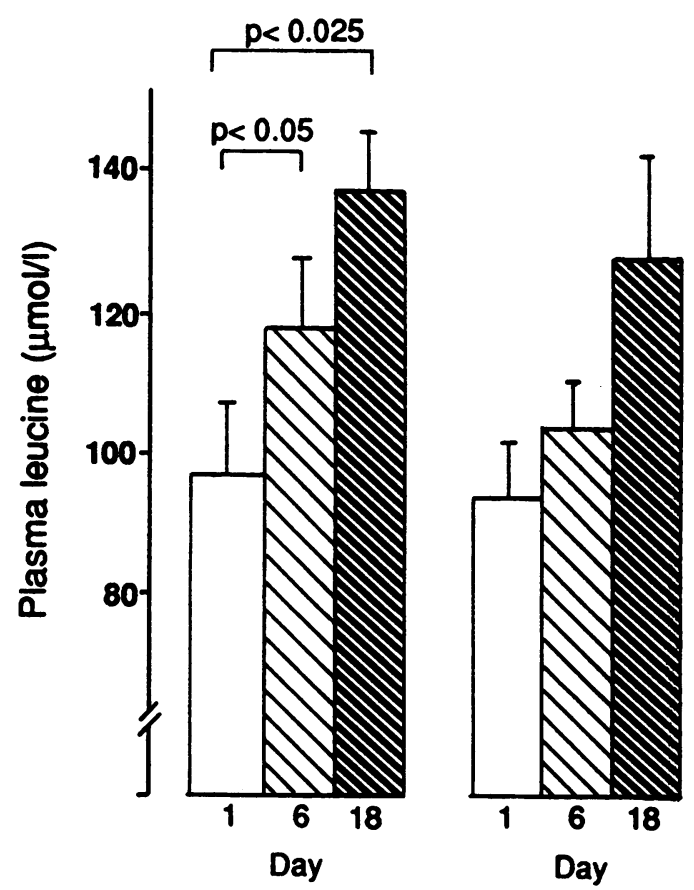

Figure 2: Variations of plasma leucine (mean (SEM)) between DI and D6 (group A: procein hydrolysate; group $B$ non-degraded protein) and between $D I$ and D 18 (group $A$ : $P H-N D P-P H$; group $B: N D P-P H-N D P$. 
TABLE III Plasma essential amino acid concentrations (umol/l) before and one hour after nutrition restart (median (range)

\begin{tabular}{|c|c|c|c|}
\hline & to & $t I$ & $\begin{array}{l}\text { Wilcoxon } \\
\text { test }\end{array}$ \\
\hline \multicolumn{4}{|l|}{ Threonine } \\
\hline $\mathrm{PH}$ & $143(73-303)$ & $151(68-326)$ & $p<0.05$ \\
\hline NDP & $132(47-242)$ & $127(59-238)$ & NS \\
\hline \multicolumn{4}{|l|}{ Valine } \\
\hline PH & $177(115-400)$ & $199(109-379)$ & $\mathrm{p}<0.02$ \\
\hline NDP & $195(199-279)$ & $208(146-293)$ & NS \\
\hline \multicolumn{4}{|l|}{ Methionine } \\
\hline PH & $23(11-46)$ & $27(11-51)$ & $\mathrm{p}<0.05$ \\
\hline NDP & $22(7-41)$ & $23(8-39)$ & NS \\
\hline \multicolumn{4}{|l|}{ Isoleucine } \\
\hline NDP & $\begin{array}{l}66(11-106) \\
63(30-101)\end{array}$ & $\begin{array}{l}77(22-115) \\
73(31-96)\end{array}$ & $\begin{array}{l}\mathrm{p}<0.01 \\
\mathrm{NS}\end{array}$ \\
\hline \multicolumn{4}{|l|}{ Leucine } \\
\hline PH & $115(73-180)$ & $145(88-200)$ & $\mathrm{p}<0.01$ \\
\hline NDP & $115(62-178)$ & $119(73-192)$ & NS \\
\hline \multicolumn{4}{|l|}{ Phenylalanine } \\
\hline PH & $61(42-101)$ & $71(48-120)$ & $\mathrm{p}<0.01$ \\
\hline NDP & $62(42-134)$ & $74(38-159)$ & $\mathrm{p}<0.02$ \\
\hline \multicolumn{4}{|l|}{ Tryptophan } \\
\hline PH & $39(26-58)$ & $42(26-67)$ & $p<0.01$ \\
\hline \multirow{2}{*}{\multicolumn{4}{|c|}{ Lysine }} \\
\hline & & & \\
\hline $\mathrm{PH}$ & $232(161-332)$ & $231(153-359)$ & $\mathrm{p}<0.01$ \\
\hline NDP & $193(125-355)$ & $193(129-413)$ & NS \\
\hline
\end{tabular}

$\mathrm{PH}=$ protein hydrolysate; $\mathrm{NDP}=$ non-degraded protein; $\mathrm{NS}=$ not significant

\section{BIOCHEMICAL PATTERNS DURING THE STUDY}

Plasma amino acid patterns over the 18 days

Plasma concentrations of leucine increased between D1 and D6 only when patients received protein hydrolysate $(n=6, p<0.05)($ Fig 2$)$.

Between D1 and D18, plasma amino acids showed an overall increase in both groups, except for phenylalanine in group A. This increase was generally more pronounced during the periods of the protein hydrolysate diet, especially with regard to branched chain amino acid concentrations. Only leucine and valine

TABLE IV Variation of plasma non-essential amino acid concentrations ( $\mu$ mol/l) before and one hour after nutrition restart (median (range))

\begin{tabular}{|c|c|c|c|}
\hline & to & $t 1$ & $\begin{array}{l}\text { Wilcoxon } \\
\text { test }\end{array}$ \\
\hline \multicolumn{4}{|l|}{ Taurine } \\
\hline $\begin{array}{l}\text { PH } \\
\text { NDP }\end{array}$ & $\begin{array}{l}56(26-253) \\
67(26-388)\end{array}$ & $\begin{array}{l}59(33-134) \\
63(36-206)\end{array}$ & $\begin{array}{l}\text { NS } \\
\text { NS }\end{array}$ \\
\hline \multicolumn{4}{|l|}{ Serine } \\
\hline $\begin{array}{l}\text { PH } \\
\text { NDP }\end{array}$ & $\begin{array}{l}89(34-114) \\
76(45-158)\end{array}$ & $\begin{array}{l}96(36-140) \\
84(41-128)\end{array}$ & $\begin{array}{l}\mathrm{p}<0.02 \\
\mathrm{NS}\end{array}$ \\
\hline \multicolumn{4}{|l|}{ Glutamate } \\
\hline $\begin{array}{l}\text { PH } \\
\text { NDP }\end{array}$ & $\begin{array}{l}96(52-308) \\
94(43-324)\end{array}$ & $\begin{array}{l}99(53-346) \\
93(36-269)\end{array}$ & $\begin{array}{l}\text { NS } \\
\mathrm{p}<0.05\end{array}$ \\
\hline \multicolumn{4}{|l|}{ Glutamine } \\
\hline $\begin{array}{l}\text { PH } \\
\text { NDP }\end{array}$ & $\begin{array}{l}554(319-863) \\
457(216-826)\end{array}$ & $\begin{array}{l}536(334-1239) \\
535(242-924)\end{array}$ & $\begin{array}{l}\text { NS } \\
\text { NS }\end{array}$ \\
\hline \multicolumn{4}{|l|}{ Proline } \\
\hline $\begin{array}{l}\text { PH } \\
\text { NDP }\end{array}$ & $\begin{array}{l}250(42-508) \\
267(35-479)\end{array}$ & $\begin{array}{l}285(50-500) \\
247(38-560)\end{array}$ & $\begin{array}{l}\mathrm{p}<0.05 \\
\mathrm{NS}\end{array}$ \\
\hline \multicolumn{4}{|l|}{ Glycine } \\
\hline $\begin{array}{l}\text { PH } \\
\text { NDP }\end{array}$ & $\begin{array}{l}270(127-322) \\
246(131-488)\end{array}$ & $\begin{array}{l}285(100-874) \\
248(127-448)\end{array}$ & $\begin{array}{l}\text { NS } \\
\text { NS }\end{array}$ \\
\hline \multicolumn{4}{|l|}{ Alanine } \\
\hline $\begin{array}{l}\text { PH } \\
\text { NDP }\end{array}$ & $\begin{array}{l}434(251-582) \\
364(156-583)\end{array}$ & $\begin{array}{l}450(234-712) \\
388(177-588)\end{array}$ & $\begin{array}{l}\mathrm{p}<0.01 \\
\mathrm{NS}\end{array}$ \\
\hline \multicolumn{4}{|l|}{ Cysteine } \\
\hline $\begin{array}{c}\text { NDP } \\
\text { Tyrosine }\end{array}$ & $67(37-136)$ & $71(37-95)$ & $\stackrel{\mathrm{p}}{\mathrm{NS}}$ \\
\hline ND & $\begin{array}{l}73(38-146) \\
77(36-162)\end{array}$ & $\begin{array}{l}87(50-149) \\
81(40-121)\end{array}$ & $\begin{array}{l}\mathrm{p}<0.05 \\
\mathrm{NS}\end{array}$ \\
\hline \multicolumn{4}{|l|}{ Ornithine } \\
\hline $\begin{array}{c}\text { NDP } \\
\text { Histidine }\end{array}$ & $\begin{array}{l}00(35-190) \\
71(35-199)\end{array}$ & $69(36-188)$ & NS \\
\hline $\begin{array}{l}\text { PH } \\
\text { NDP }\end{array}$ & $\begin{array}{l}76(45-111) \\
80(26-161)\end{array}$ & $\begin{array}{l}80(42-112) \\
72(22-174)\end{array}$ & $\begin{array}{l}\text { NS } \\
\text { NS }\end{array}$ \\
\hline \multicolumn{4}{|l|}{ Arginine } \\
\hline $\begin{array}{l}\text { PH } \\
\text { NDP }\end{array}$ & $\begin{array}{l}59(33-92) \\
62(30-189)\end{array}$ & $\begin{array}{l}61(36-102) \\
60(32-197)\end{array}$ & $\begin{array}{l}\text { NS } \\
\text { NS }\end{array}$ \\
\hline
\end{tabular}

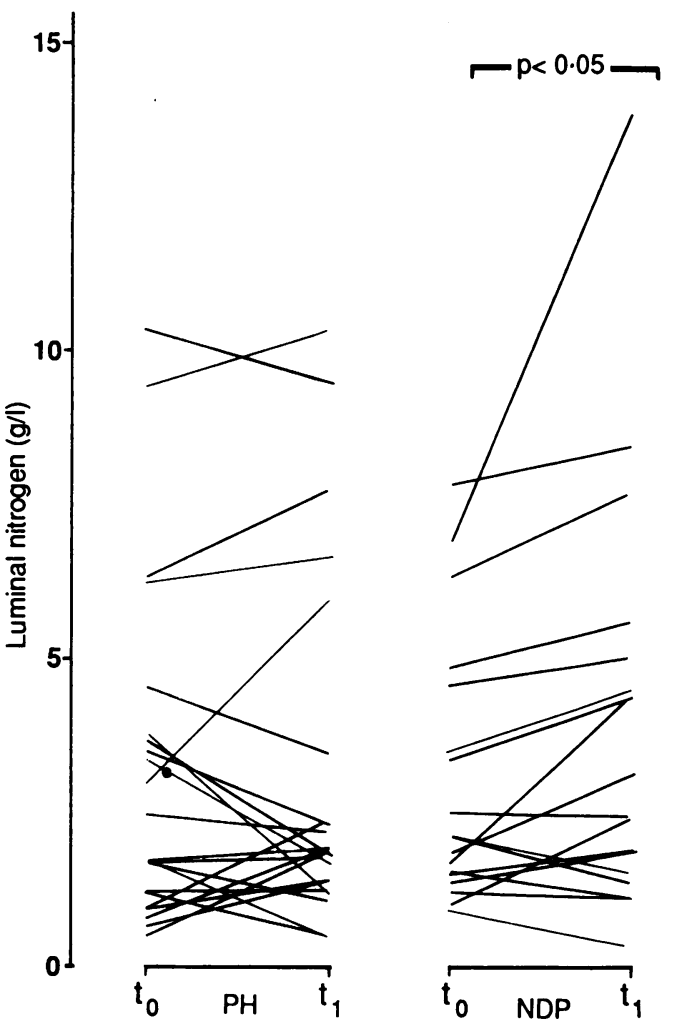

Figure 3: Variations of luminal nitrogen one hour after nutrition restart. PH and NDP both contained (mean $(S D)) 5 \cdot 1(0 \cdot 7) \mathrm{g}$ nitrogen/l.

increased significantly, however; plasma valine increased in both groups (data not shown), but plasma leucine only in group A (Fig 2).

Dynamic study of plasma and luminal amino acids: $t l \mathrm{v} t 0$

$\mathrm{t} 1$ and $\mathrm{t} 0$ values of the 20 amino acids studied were compared independently of the day of measurement since the $(\mathrm{t} 1-\mathrm{t} 0)$ differences on different days were similar. As an example, the $(\mathrm{t} 1-\mathrm{t} 0)$ differences for plasma leucine were as follows (mean (SD)):

Protein hydrolysate diet: $\mathrm{Dl}=+23$ (12), $\mathrm{D} 6=+22(35), \mathrm{D} 12=+15(26), \mathrm{D} 18=+22(23)$ $\mu \mathrm{mol} / \mathrm{l}$.

Non-degraded protein diet: $\mathrm{D} 1=+12(26)$, $\mathrm{D} 6=+16(25), \mathrm{D} 12=+12(34), \mathrm{D} 18=-4(28)$ $\mu \mathrm{mol} / \mathrm{l}$.

A significant increase occurred in plasma concentrations of 13 amino acids (including all the essential amino acids) with the protein hydrolysate diet compared with an increase in only two with the non-degraded protein diet. Results concerning the essential amino acids are given in Table III; results for the 12 remaining amino acids are given in Table IV.

In the lumen large variations were observed in t0 values (after a three hour fast) for nitrogen, total protein, and amino acid concentrations. to values, however, did not show significant differences in terms of the diet which preceded the measurements. After sampling, nutrition was restarted at a rate of $144(19) \mathrm{ml} / 24$ hours giving $5 \cdot 2(0 \cdot 7) \mathrm{g}$ nitrogen/l (mean (SD), $\mathrm{n}=32$ ) for both diets. The $(t l-t 0)$ variations in nitrogen, total proteins, and amino acids could thus be studied:

Luminal concentrations of nitrogen were 
TABLE V Variation of plasma insulin concentrations ( $m U / l)$ (median (range))

\begin{tabular}{llll}
\hline & $t 0$ & $t l$ & Wilcoxon test \\
\hline Protein hydrolysate & $10 \cdot 0(3 \cdot 7-38 \cdot 8)$ & $32 \cdot 0(10 \cdot 0-122 \cdot 4)$ & $\mathrm{p}<0.01$ \\
Non-degraded protein & $19 \cdot 0(2 \cdot 3-29 \cdot 8)$ & $15 \cdot 4(4 \cdot 9-64 \cdot 4)$ & NS \\
\hline
\end{tabular}

significantly higher at $\mathrm{t} 1$ than at $\mathrm{t} 0$ with nondegraded protein (Fig 3).

Luminal total protein concentrations decreased by $2 \mathrm{~g} / \mathrm{l}$ at $\mathrm{tl}$ with protein hydrolysate but increased by $1 \mathrm{~g} / \mathrm{l}$ with non-degraded protein (data not shown).

To compare the amount of luminal free amino acids after one hour's nutrition with protein hydrolysate or non-degraded protein mean (tlt0) values were determined for each amino acid and for each diet. The $(\mathrm{t} 1-\mathrm{t} 0)$ value was higher for non-degraded protein than for protein hydrolysate $(-5 \mu \mathrm{mol} / \mathrm{l}$ (interval: -383 to +82$) v$ $-108 \mu \mathrm{mol} / 1 \quad(-405$ to +155$), \mathrm{p}<0.05)$. As values at t0 were similar for both diets, the amount of free amino acids at $t 1$ was significantly higher with non-degraded protein than with protein hydrolysate.

\section{Insulin secretion and correlation with amino acid concentrations}

The administration of protein hydrolysate led to a significant increase in plasma insulin at $\mathrm{t} l v \mathrm{t} 0$, whereas this was not the case with non-degraded protein (Table V).

tl values of leucine, phenylalanine, and alanine correlated with tl values of insulin only with protein hydrolysate $(\mathrm{p}<0.01, \mathrm{p}<0.05$, $\mathrm{p}<0.05$, respectively). The results for leucine are shown in Figure 4. In addition, $(t 1-t 0)$ differences in plasma lysine and insulin concentrations correlated only when the patients received protein hydrolysate $(\mathrm{p}<0.025)$.

\section{Nitrogen excretion and balance}

Urinary nitrogen excretion was slightly higher in group B (NDP-PH-NDP) during each period. Inversely, nitrogen losses in faeces and stoma were lower in this group, resulting in no significant difference in nitrogen balance between the two groups (Table VI).

\section{Nutritional markers (Table VII)}

Concentrations of albumin, transferrin, transthyretin, and retinol binding protein rose in both groups during the study, but in group A (PH-NDP-PH) there was a significant increase at D18 $v$ D1 in three of the proteins, whereas only

TABLE VI Nitrogen patterns (median (range))

\begin{tabular}{|c|c|c|c|c|}
\hline & Group & D6 & $D 12$ & D18 \\
\hline $\begin{array}{l}\text { Urinary nitrogen } \\
\text { losses }(g / 24 \mathrm{~h}) \\
\text { Faeces }+ \text { stoma nitrogen } \\
\text { losses }(\mathrm{g} / 24 \mathrm{~h}) \\
\text { Nitrogen balance } \\
(\mathrm{g} / 24 \mathrm{~h})\end{array}$ & $\begin{array}{l}\mathbf{A} \\
\mathbf{B} \\
\mathbf{A} \\
\mathbf{B} \\
\mathbf{A} \\
\mathbf{B}\end{array}$ & $\begin{array}{l}4 \cdot 9(4 \cdot 1-9 \cdot 3) \\
7 \cdot 6(5 \cdot 5-9 \cdot 8) \\
4 \cdot 6(1 \cdot 3-8 \cdot 4) \\
1 \cdot 3(0 \cdot 7-3 \cdot 6) \\
+9 \cdot 0(+5 \cdot 8-+10 \cdot 8) \\
+6 \cdot 3(+4 \cdot 7-+10 \cdot 1)\end{array}$ & $\begin{array}{l}6 \cdot 3(3 \cdot 5-9 \cdot 6) \\
8 \cdot 0(6 \cdot 6-13 \cdot 9) \\
3 \cdot 3(0 \cdot 3-4 \cdot 8) \\
2 \cdot 3(0 \cdot 4-3 \cdot 2) \\
+9 \cdot 4(+7 \cdot 3-+13 \cdot 2) \\
+6 \cdot 5(+4 \cdot 1-+12 \cdot 6)\end{array}$ & $\begin{array}{l}5 \cdot 4(4 \cdot 4-10 \cdot 2) \\
7 \cdot 6(5 \cdot 9-12 \cdot 7) \\
4 \cdot 3(1 \cdot 6-9 \cdot 3) \\
1 \cdot 4(1 \cdot 2-3 \cdot 1)^{\star \star} \\
+8 \cdot 6(-0 \cdot 5-+12 \cdot 8) \\
+7 \cdot 6(+4 \cdot 7-+12 \cdot 9)\end{array}$ \\
\hline
\end{tabular}

*Mean of values obtained at the end of each nutritional period (individual values were calculated as the mean of the last three days of each six-day period).

$\star \star \mathrm{p}<0.01$ compared to protein hydrolysate during the same period (Mann-Whitney U test).

Group A: PH-NDP-PH; Group B: NDP-PH-NDP.

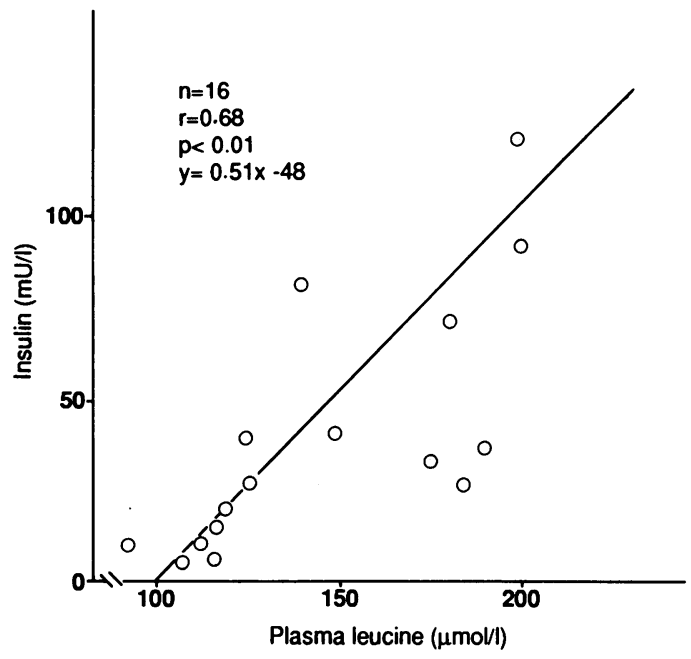

Figure 4: Correlation between concentrations of plasma leucine and insulin one hour ( 11$)$ after protein hydrolysate nutrition restart.

transthyretin increased significantly in group B at D6.

The plasma phenylalanine/tyrosine ratio decreased significantly in group A but did not change in group $B$.

A significant decrease in the urinary 3-methylhistidine/creatinine ratio occurred between D1 and D6 with protein hydrolysate. No significant difference was observed between D1 and D18 in either group.

\section{Discussion}

At the beginning of the study the patients' clinical conditions (intestinal transit, haemodynamic state) had stabilised and the two treatment groups were comparable in clinical and biological terms.

The longitudinal study of plasma amino acids essentially showed an increase in branched chain amino acids (particularly leucine) in group A (PH-NDP-PH). The dynamic study confirmed and extended these results, since the concentrations of 13 of the 20 plasma amino acids studied (including the eight essential amino acids) rose after one hour of protein hydrolysate infusion against only two with non-degraded protein.

We chose to measure plasma amino acids one hour after nutrition restart since studies performed in humans have shown that this time corresponds to the absorption peak of most amino acids before their tissue uptake, ${ }^{2324}$ although these studies concerned diets administered by bolus, not by continuous enteral nutrition. In addition, the absorption process may be delayed or have a flatter profile in digestive surgical patients. ${ }^{20}$ Finally, it cannot be excluded that the absorption peak with non-degraded protein was only shifted in time compared to protein hydrolysate.

T1 values were compared with t0 values independently of the day of study because ( $t 1-$ t0) differences were comparable regardless of the day of study.

The large degree of interindividual variations might be related to the existence and extent of intestinal resection and, above all, to metabolic differences in the small bowel and the liver. In 
TABLE VII Variation of nutritional markers according to the diet sequence (NDP-PH-NDP or $P H-N D P-P H)$ (median (range))

\begin{tabular}{|c|c|c|c|c|}
\hline & Group & $D 1$ & D6 & $D 18$ \\
\hline Albumin $(g / l)$ & A & $30(26-33)$ & $31(26-33)$ & $37(32-40)^{\star}$ \\
\hline & B & $30(24-35)$ & $30(24-42)$ & $33(28-41)$ \\
\hline Transferrin $(\mathrm{g} / \mathrm{l})$ & A & $2 \cdot 10(1 \cdot 6-2 \cdot 4)$ & $2 \cdot 25(1 \cdot 8-2 \cdot 6)$ & $2 \cdot 85(2 \cdot 3-3 \cdot 0)^{\star}$ \\
\hline & B & $2 \cdot 07(1 \cdot 3-3 \cdot 2)$ & $2 \cdot 88(1 \cdot 8-3 \cdot 5)$ & $2 \cdot 35(1 \cdot 4-3 \cdot 3)$ \\
\hline Transthyretin (g/l) & $\mathrm{A}$ & $0.26(0 \cdot 12-0.37)$ & $0.30(0.22-0.59)$ & $0.37(0.25-0.54)$ \\
\hline & B & $0.25(0.15-0.41)$ & $0.31(0 \cdot 18-0.45)^{\star}$ & $0.36(0.22-0.46)$ \\
\hline Retinol binding protein & $\begin{array}{l}\text { A } \\
\text { B }\end{array}$ & $\begin{array}{l}45(20-74) \\
50(43-83)\end{array}$ & $\begin{array}{l}54(25-64) \\
64(38-78)\end{array}$ & $\begin{array}{l}66(31-85)^{\star} \\
69(28-85)\end{array}$ \\
\hline Plasma phenylalanine/ & $\begin{array}{l}\text { B } \\
\text { A }\end{array}$ & $\begin{array}{l}50(43-83) \\
0.85(0.8-1.3)\end{array}$ & $0.81(0.6-1 \cdot 1)$ & $0.76(0.5-1.0)^{\star}$ \\
\hline tyrosine & B & $1.09(0 \cdot 6-1 \cdot 3)$ & $0.79(0.7-1.5)$ & $0.82(0.6-1.5)$ \\
\hline Urinary 3-methylhistidine/ & A & $24(18-36)$ & $21(16-26)^{\star}$ & $22(18-35)$ \\
\hline creatinine $(\mu \mathrm{mol} / \mathrm{mmol})$ & B & $22(2-33)$ & $25(9-49)$ & $22(15-40)$ \\
\hline
\end{tabular}

${ }^{\star} \mathrm{p}<0.05$ compared with results at $\mathrm{Dl}$ (Mann-Whitney $\mathrm{U}$ test)

Group A: PH-NDP-PH; Group B: NDP-PH-NDP.

this clinical study, however, it was impossible, for ethical reasons, to perform portal catheterisation. None the less, it is interesting that in pigs receiving a 30 minute intestinal infusion of $100 \mathrm{~g}$ protein hydrolysate, portal blood concentrations of $\alpha$ amino nitrogen are higher than when whole proteins are infused under the same conditions. ${ }^{25}$

The higher tl plasma amino acid concentrations observed with the protein hydrolysate diet cannot be directly ascribed to a higher absorption rate because it is well known that large amounts of most amino acids are metabolised by splanchnic areas after a meal. Branched chain amino acids are a notable exception, large amounts escaping liver metabolism. ${ }^{242627}$ The increase in these amino acids in the peripheral blood therefore seem to reflect their intestinal absorption. The results for leucine are particularly interesting since the concentration of leucine is depressed after surgery ${ }^{28}{ }^{29}$ and since leucine might be capable of reducing liver protein breakdown and enhance protein synthesis in muscle. ${ }^{3031}$

No $t 1$ increase in the peripheral blood concentrations of several amino acids was observed with either diet. This had previously been reported for glutamate and glutamine, which are directly and actively metabolised in enterocytes. ${ }^{2632} 33$

With regard to insulin secretion, an increase was observed in plasma concentrations at $t 1$ only with protein hydrolysate. This result should be considered in the light of the findings that insulin reduces protein breakdown ${ }^{34} 35$ and enhances muscle and tissue uptake of branched chain amino acids, ${ }^{23}$ particularly leucine. ${ }^{35}$ The position in time of the insulin peak is subject to variations according to species and bioclinical state, as well as the form and quantity of nutrients. In general it occurs at around 30 minutes in animals ${ }^{27} 3637$ and 60 minutes in humans. ${ }^{23839}$ In our study the patients received the same quantity of nutrients, including nitrogen, but, as the form of nitrogen was different (oligopeptides $v$ whole proteins), the insulin peak may have been shifted in time in those patients receiving non-degraded protein. This point requires further study. After the infusion of protein hydrolysate, a correlation was found between insulin concentrations and the peripheral increases in four amino acids. This correlation was especially clear for leucine, an amino acid that strongly stimulates insulin secretion. ${ }^{+0}$ Our results concerning the parameters of protein metabolism might be explained by the finding that amino acids are physiological stimuli of insulin secretion ${ }^{41}$ and by the known nitrogen sparing effect of this hormone. In effect, the anticatabolic action of the protein hydrolysate diet could be reflected ${ }^{+2}$ by the significant decrease observed in the 3-methylhistidine/ creatinine ratio between D1 and D6 and in the phenylalanine/tyrosine ratio between D1 and D18, these ratios remaining unmodified during the corresponding periods with the nondegraded protein diet.

The study of intraluminal nitrogen, total protein, and amino acids showed large variations with time. This may be related partly to the large amount of endogenous protein present in the lumen (about one third of total luminal protein in healthy subjects), ${ }^{7}$ and to possible individual differences in secretory activity in these patients who had undergone abdominal surgery. This would minimise differences in the results between protein hydrolysate and non-degraded protein. In effect, the trend in luminal total protein concentrations was towards an increase at $\mathrm{t} l$ with non-degraded protein and a reduction with protein hydrolysate, although the difference was not significant. Such results are logical, given that non-degraded protein contains whole proteins, whereas only 7 per 100 peptides in protein hydrolysate have a molecular weight above 1000 . The fact that each patient was his or her own control, however, allowed certain differences in luminal parameters between protein hydrolysate and non-degraded protein to be identified. Non-degraded protein led to a (tlt0) rise in the luminal concentration of nitrogen, whereas protein hydrolysate did not. Moreover, the luminal concentrations of free amino acids at tl were higher with non-degraded protein than with protein hydrolysate, although the latter contains 30 free amino acids per 70 peptides. These results could be due to a more rapid absorption of nitrogen with the protein hydrolysate diet and might explain the simultaneous peripheral increase in amino acids.

The study of nitrogen balance showed no significant difference between the two dietary groups. The administration of protein hydrolysate tended to reduce urinary nitrogen losses, whereas non-degraded protein improved nitrogen retention in the small bowel. The high infusion rate $(144 \mathrm{ml} / \mathrm{h})$ could be responsible for the increase in nitrogen excretion in the chyme and faeces observed with protein hydrolysate, together with the lower viscosity of this predigested diet. Our results therefore seem to differ somewhat from those of Poullain et al, who recently reported that an oligopeptide based diet was more efficient than a whole protein diet with regard to urinary nitrogen losses and nitrogen balance in a rat model.

Both protein hydrolysate and non-degraded protein had a positive effect on visceral protein concentrations but, whereas non-degraded protein only acted on the concentrations of transthyretin, protein hydrolysate also enhanced the synthesis of albumin, transferrin, and retinol binding protein. The D0 concentration of transthyretin and retinol binding protein were normal and those of albumin and transferrin were slightly reduced. As the study took place (mean 
(SD)) 23 (13) days after surgery, the values of the short half life proteins (transthyretin, retinol binding protein) might have returned to normal before the study, whereas those of the longer half life proteins (albumin, transferrin) might have continued to increase during the study..$^{28}$ Again the effect of protein hydrolysate on the specific proteins could be related to its effect on insulin secretion, since insulin is known as a potent stimulator of hepatic protein synthesis.

We thank Mrs A Cretel for technical help, Mrs P Jue for expert secretarial skills, and $\mathrm{Mr} \mathrm{D}$ Young for help in preparing this text. We are grateful to Mrs V Jaussan (Roussel UCLAF-Nutrition, Usine de Creully, France) for valuable information on Reabilan and the whole protein diet.

1 Randal HT. Enteral nutrition: tube feeding in acute chronic illness. FPEN 1984; 8: 113-36.

2 Levy E, Huguet C, Parc R, Ollivier JM, Goldberg J, Loygue J. Continuous high-energy low-flow-rate enteral support: a panoramic review of 1000 cases. Life Support Syst 1985; 3 : panoramic

3 Wilmore DW, Black PR, Muhlbacher F. Injured man: trauma and sepsis. In: Nutritional support of the seriously ill patient. London: Academic Press, 1983: 33-52.

4 Chandra RK. Nutrition, immunity and infection: present knowledge and future directions. Lancet 1983; i: 688-91.

5 Elia M, Carter A, Bacon S. Excretion usefulness of urinary 3methylhistidine excretion in indicating muscle protein breakdown. BrMed $\mathcal{F} 1981 ; 282: 351-4$.

6 Messing B, Bernier JJ. Optimal TPN infusion rate in patients with gastrointestinal disease and malnutrition. Effects of 2 energy nitrogen ratios. FPEN 1980; 4: 272-6.

7 Grimble GK, Silk DBA. The optimum form of dietary nitrogen in gastrointestinal disease: proteins, peptides or amino acids? In: Verhandlungen der Deutschen Gesellschaft für Innere Medizin. 92. Band. München, JF Bergmann Verlag, 1986: 674-85.

8 Fairfull-Smith R, Abunassar R, Freeman JB, Maroun JA. Rational use of elemental and non elemental diets in Rational use of elemental and non elemental
hospitalized patients. Ann Surg 1980;192: 600-3.

9 Adibi SA. Intestinal transport of dipeptides in man: relative importance of hydrolysis and intact absorption. $\mathcal{F}$ Clin Invest 1971; 50: 2266-75.

10 Matthews DM, Adibi SA. Peptide absorption. Gastroenterology 1976; 71: 151-61.

11 Silk DBA, Hegarty JE, Fairclough PD, Clark ML. Characterization and nutritional significance of peptide transport in man. Ann Nutr Metab 1982; 26: 337-52.

12 Chung YC, Silk DBA, Kim YS. Intestinal transport of a tetrapeptide, L-leu-glycylglycylglycine, in rat small intestine in vivo. Clin Sci 1979; 57: 1-11.

13 Silk DBA. Peptide transport. Clin Sci 1981; 60: 607-15.

14 Ganapathy V, Leibach FH. Peptide transport in intestinal and renal brush border membrane vesicles. Life Sci 1982; 30: $2137-46$.

15 Grimble GK, Keohane PP, Higgins BE, Kaminski MV, Silk DBA. Effect of peptide chain length on amino acid and nitrogen absorption from two lactalbumin hydrolysates in the normal human jejunum. Clin Sci 1986; 71: 65-9.

16 Grimble GK, Rees RG, Keohane PP, Cartwright T, Desreumaux M, Silk DBA. Effect of peptide chain length on absorption of egg protein hydrolysates in the normal human jejunum. Gastroenterology 1987; 92: 136-42.

17 Andersson H, Bosaeus I, Ellegard L, Hallgren B, Hulten L, Magnusson O. Comparison of an elemental and two polymagnusson O. Comparison of an elemental and two polymeric diets in colectomized patients with

18 Russel CA, Evans SJ. A comparison of the absorption from a 'chemically defined elemental' and a 'whole protein' enteral feed by the human small bowel. Clin Nutr 1987; 6: 127-30.

19 Moriarty KJ, Hegarty JE, Fairclough PD, Kelly MJ, Clark ML, Dawson AM. Relative nutritional value of whole protein, hydrolysed protein and free amino acids in man. Gut 1985; 26: 694-9.

20 Simko V, Chen MH. Hormonal responses to complete or hydrolysed protein diets in patients after upper gastrointestinal surgery. 7 Am Coll Nutr 1986; 5: 383-91.

21 Levy E, Palmer DL, Frileux P, Parc R, Huguet C, Loygue J. Inhibition of upper gastrointestinal secretions by reinfusio of succus entericus into the distal small bowel. Ann Sur 1983; 198: 596-600.

22 Cynober L, Coudray-Lucas C, Ziegler F, Giboudeau J. High performance ion exchange chromatography of amino acids in biological fluids using Chromakon 500. Performance of the apparatus. F Automat Chem 1985; 7: 201-3.

23 Schweiger U, Warnhoff M, Pahl J, Pirke KM. Effects of carbohydrate and protein meals on plasma large neutra amino acids, and insulin plasma levels of anorectic patients. Metabolism 1986; 35: 938-43.

24 Ashley DV, Barclay DV, Chauffard FA, Moennoz D, Leathwood PD. Plasma amino acid responses in human to evening meals of differing nutritional composition. $A m \mathcal{F}$ Clin Nutr 1982; 36: 143-53.

25 Rerat AA. Intestinal absorption of end products from digestion of carbohydrates and proteins in the pig. Arch Tierernahr 1985; 35: 461-80.

26 Bergman EN. Splanchnic and peripheral uptake of amin acids in relation to the gut. Fed Proc 1986; 45: 2277-82.

27 Barret EJ, Gusberg R, Ferrannini E, et al. Amino acid an glucose metabolism in the postoperative state and followin amino acid ingestion in the dog. Metabolism 1986; 35: 709 17.

28 Shenkin A, Neuhauser M, Bergstrom J, et al. Biochemica changes associated with severe trauma. Am f Clin Nutr 1980 33: 2119-27.

29 Cerra FB. Hypermetabolism, organ failure, and metabolic support. Surgery 1987; 101: 1-14.

30 Walser $M$. Nitrogen sparing effect of branched-chain keto acids. New aspects of clinical nutrition. Basel: Karger, 1983: 319-24.

31 Smith TK. Effect of leucine-rich dietary protein on in vitro protein systhesis in porcine muscle. Proc Soc Exp Biol Med 1985; 180: $538-43$.

32 Webb KE. Amino acid and peptide absorption from the gastrointestinal tract. Fed Proc 1986; 45: 2268-71.

33 Alpers DH. Uptake and fate of absorbed amino acids and peptides in the mammalian intestine. Fed Proc 1986; 45 2261-7.

34 Woolfson AMJ, Heatley RV, Allison SP. Insulin to inhibi protein catabolism after injury. $N$ Engl $\mathcal{f}$ Med 1979; 300: 14-7.

35 Odessey R, Parr B. Effect of insulin and leucine on protei turnover in rat soleus muscle after burn injury. Metabolis 1982; 31: 82-7.

36 Bloomgarden ZT, Liljenquist J, Lacy W, Rabin D. Amin acid disposition by liver and gastrointestinal tract after protein and glucose ingestion. Am f Physiol 1981; 241: E90-E99.

37 Swenne I, Crace CJ, Milner DG. Persistent impairment of insulin secretory response to glucose in adult rats after limited period of protein-calorie malnutrition early in life. Diabetes 1987; 36: 454-8.

38 Krezowski PA, Nuttall FQ, Gannon MC, Bartosh NH. The effect of protein ingestion on the metabolic response to ora effect of protein ingestion on the metabolic response to ora glu.

39 Nuttal FQ, Gannon MC, Wald JL, Ahmed H. Plasma glucose and insulin profiles in normal subjects ingesting diets of varying carbohydrate, fat, and protein content. $\mathcal{7} \mathrm{Am} \mathrm{Coll}$ Nutr 1985; 4: 437-50.

40 Vara E, Tamarit-Rodriguez J. Effect of $L$-leucine on palmitate metabolism and insulin release by isolated islets of fed and starved rats. Endocrinology 1986; 119: 404-7.

41 Floyd JC, Fajans SS, Conn, JW, Knopf RF, Rull J. Stimulation of insulin secretion by amino acids. $\mathcal{F}$ Clin Invest 1966 45: 1487-502.

42 Prabhakaran VM, Pujura S, Mills AJ, Whalen VW. Can nutritional criteria help predict outcome in hospitalized patients? Clin Chem 1986; 32: 2077-9.

43 Poullain MG, Cezard JP, Roger L, Mendy F. Effect of whey proteins, their oligopeptide hydrolysates and free amin acid mixtures on growth and nitrogen retention in fed an

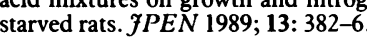

